\title{
AN ECONOMIC PERSPECTIVE AND POLICY IMPLICATION FOR SOCIAL ENTERPRISE
}

\author{
${ }^{1}$ Yoon-Doo Kim, ${ }^{2}$ Seok Yoon and ${ }^{3}$ Heon-Goo Kim \\ ${ }^{1}$ College of International Business, Division of International Trade and Culture, Konkuk University, \\ 322 Danwol-Dong, Chungju-Si, Chungcheonbuk-do, 380-701, Korea \\ ${ }^{2}$ Department of Social Enterprise, Graduate School of Business Administration, Gachon University, \\ 342 SeongnamDaero Sujeong-Gu, Seongnam-Si, Gyeonggi-do 461-701, Korea \\ ${ }^{3}$ Agriculture and Life Sciences Research Institute, Kangwon National University, 1 Kangwondaehak-gil, \\ Chuncheon-si, Gangwon-do, 200-701, Korea
}

Received 2013-04-26; Revised 2013-07-04; Accepted 2014-01-07

\begin{abstract}
This study looked at the current status of Korean social enterprises and their problems and suggested governmental policy implications for enhancing the competitiveness of social enterprises. As the study methods, the current status of social enterprises was analyzed and performance of social enterprise support was examined and then policy implications for promoting the social enterprises were analyzed. First, the direction of governmental policy regarding the promotion of social enterprise should be converted into the ecosystem oriented or each business oriented getting out of the labor cost oriented and should emphasize on the follow up management and evaluation. Second, the certification program that bothers the expansion of social enterprises should be changed. That is, the government should change a policy into the direction that leaves the activities of social enterprise to the market function while easing the criteria of certification. Only by this, can more activities and job creation effects of social enterprise be expected. Third, the directions of governmental policies related to social entrepreneur fostering should be corrected and complemented. To resolve this so called problem, a standard model including the policy of standardized programs and contents for each business, type and local autonomous entity needs to be suggested. The educational programs and contents composed of such a standard model can enhance the professionalism and efficiency in social entrepreneur fostering. Finally the concept of social economy is needed to be more wide spread. That is, as a base of social enterprise activity, systematic and professional educational programs through university or graduate school are required. In Korea, for social enterprise to develop, excessive governmental involvement in the market should decrease. That is, the certification requirement for social enterprise should be eased much and a direct support for social enterprise should be converted into an indirect support method, which enables more activities of social enterprise and higher job creation effect. In the long term, social entrepreneurs should be fostered to enhance professionalism and efficiency so that social enterprise can have competitiveness.
\end{abstract}

Keywords:Social Enterprise, Social Entrepreneurship, Social Enterprise Policy, Social Entrepreneurs, South Korea

\section{INTRODUCTION}

Social enterprise originated in Europe and it is after 1997, that is, after so-called IMF economic crisis that social enterprise started to be publicly considered in South Korea (hereinafter called, Korea). At that time, rather than the social enterprise policy, the job creation policy by the governmental finance support as a means for overcoming economic crisis showed more effects. After the 2000's, several problems such as economic growth without employment and an increase in social service demands occurred, thus the

Corresponding Author: Seok Yoon, Department of Social Enterprise, Graduate School of Business Administration, Gachon University, 1342 Seongnam Daero Sujeong-Gu, Seongnam -Si, Gyeonggi-Do 461-701, Korea 
adoption of European social enterprise system was widely discussed.

During the above process, the Social Enterprise Promotion Act (July 2007) was enforced and the social job creation business gained some performances as a model that created profits and sought self-reliance. In addition, thanks to the stable job creation and social service provision using the 3rd sectors such as the governmental non-profit corporate and group, the social enterprise policy started to be rooted.

In Korea, the directions of social enterprise are developing into the employment creation for a vulnerable social group, social integration, provision of service needed by social communities and welfare level of job creation. That is, after the enforcement of Social Enterprise Promotion Act, the Korean government took the lead in deciding the priority order of policies and progressed the fostering and boosting of social enterprises through financial support.

As a result, as social enterprise policy effects, the number of social enterprises after five years of the said Act enforcement reached 565 (September 30, 2011) and the number of employed workers over all social enterprises was 15,000 and among them employees from the vulnerable social group exceeded around 9,000. Like this, it can be evaluated that social enterprises have been rapidly grown due to enormous demands for welfare based on the welfare pluralism and know-how accumulated in the economic growth process.

However, the 'easy credit' discussion (SN, 2011) related to social enterprise comes to the forefront recently. After the budget support for the job creation related business ended, the cancelling of employment occurs and the budget is wasted due to insufficient follow-up management. These phenomena can be called, the side effect of government involvement or moral hazard of which both are undesirable. Thus these side effects should be minimized and the system established for boosting social enterprise as a long term enterprise is required.

Accordingly the purpose of this study is to look at the current status and problems of Korean social enterprise and in the middle-long term, suggest the governmental policy measures necessary for boosting social enterprise. The study methods are as follows: The growth and development process of Korean social enterprise were looked at through literature studies and policy implications were found throughout reciprocal comparison with development of social enterprises of main countries where social enterprises develop.

\section{CURRENT STATUS OF SOCIAL ENTERPRISE AND PERFORMANCE OF SOCIAL ENTERPRISE POLICY}

\subsection{Current Status of Social Enterprise}

Social enterprise is defined to be a company (organization) that performs economic activities such as production and sales of goods and services, while firstly seeking the public interest, which is a social purpose. That is, if a company wants to be a social enterprise, the company should meet the requirements of an organization while performing economic activities. The examples of the said requirements are: Creates jobs or provides social services to the vulnerable social group or seeks social purposes such as the community public interest. In the case of Korea, according to the Social Enterprise Promotion Act, for economic activities of a company as social enterprise, the company should meet formal requirement of certification of the minister of the Ministry of Employment and Labor in addition to an actual requirement so called public interest. The legal requirements or definitions of such social enterprise are different for each country and their historical backgrounds are also different.

\subsubsection{Current Status of Certification}

The public activity of Korean social enterprise started as the Beautiful Store Co. (October 2007) and was certified as No.1 of social enterprise by the Ministry of Employment and Labor. Given Table 1, after social enterprise was certified in 2007 for the first time, certified enterprises rapidly increased every year and on the basis of the end of June, 2012, 656 social enterprises deploy activities nationwide

Moreover, the number of preliminary social enterprise certification increased from 396 in 2007 to 1,340 . The number of employees from vulnerable social group who were successfully employed and affected by the activities of social enterprises exceeded ten thousands and the number of total employees of social enterprise exceeds 16,000 .

Let's look at the social enterprise for each type (Basis of Aug. 30, 2011). The type of social job creation is $330(59.5 \%)$, which occupies the absolute majority and the type of social service provision is $46(8.3 \%)$ and the mixed type of the above both accounts for $17.1 \%$. In addition, considering the distribution for each organization form, the company according to the Commercial Law was $40.4 \%$, which was the most and the corporation according to the Civil Law was $25.6 \%$. 
Table 1. Current status of certification and employment of social enterprise

\begin{tabular}{lllllll}
\hline & 2007 & 2008 & 2009 & 2010 & 2011 & End of June, 2012 \\
\hline Certified enterprise(number) & 50 & 208 & 285 & 501 & 644 & 656 \\
Preliminarycertifiedenterprise(number) & 396 & 602 & 646 & 961 & 1,260 & 1,340 \\
Number of emploueerfromvulmeravlesocialgroup & 1,403 & 4,832 & 6,467 & 8,227 & 10,018 & 10,082 \\
Totalemployees of social enterprise & 2,539 & 8,329 & 11,150 & 13,443 & 16,319 & 16,406 \\
\hline
\end{tabular}

Note: (1) The preliminary social enterprises were certified by the local autonomous entities. (2) Accumulation value Source: MEL (2012)

Also non-profit group, $19.3 \%$ and social welfare corporation, $11.9 \%$ respectively so both of them accounted for one third of the overall social enterprises (KED, 2011).

Thus, the characteristics of social enterprise activities in Korea are as follows: Many social enterprises were certified for a short term and they contributed to job creation as much. That is, the policy of the supporting and fostering of social enterprise sought by the Korean government takes effect. These policy effects can be evaluated to be so much remarkable as hardly to be found in any other countries over the world.

\subsubsection{Support System for Social Enterprise}

The support system for social enterprise can be divided into a direct support and indirect support that supports the ecosystem of overall social enterprises. That the ecosystem is supported as the indirect support means that management environments regarding company management and profit creation are improved and social entrepreneurs are fostered, so an ecosystem that is good for running businesses is formed. Here, this ecosystem means the followings in detail: The creation of social enterprise is supported and it is easier to achieve management innovation.

First, the direct support is based on the Social Enterprise Promotion Act and its details are, (i) Management support, (ii) Support of tax such as corporate tax and income tax and support of social insurance fees, (iii) Financial support that supports the professional personnel and the labor cost of social job (iv) Support of business development costs for management abilities improvement related to technological development, R\&D, publicity and marketing and these details can be summarized as shown in Table 2.

Second, the indirect supports include the support for establishment of network for each region and for each business type and expert network and pro bono in addition to fostering and supporting social entrepreneurs. The programs for training social entrepreneurs include the academy and education business for social entrepreneurs, training of youth social entrepreneurs and support of social venture business.
Here, when compared to the current status of employment of foreign social enterprises, the results are as shown in Table 3. When compared to the number or current status of employment of social enterprises of main countries, the number or employees of Korean social enterprises is relatively insufficient compared to the US, Canada and Britain.

In addition, in the case of Korea, the average employment number per social enterprise is 24 so the employment rate showing the employees of social enterprises is $0.06 \%$, which is remarkably lower compared to that of US and Britain and also shows a much lower level than $7.92 \%$, which is the average employment rate in social sector of OECD 15 countries (Lee, 2010).

Like this, when the current status or employee number of social enterprises is compared to those of foreign countries, the development of Korean social enterprises cannot help being called insignificant. However, given the performances sought by the Korean government policies, while the civil awareness of the social enterprise in the market is enhanced, the involvement of NGO groups, conglomerates and religious groups increases. Also MOU conclusion between governmental sectors for social enterprise fostering and the formation and operation of consultative bodies make the cooperative system between the ministries more reinforced. In particular, conglomerates actively involve the establishment and support of social enterprise, which expands job opportunities for vulnerable social group and increases income, so it is evaluated that the self-reliance ability of social enterprise has been improved (MEL, 2011a).

In this status, the Korean government has planned to support the finding and fostering system of social enterprises not only based on conglomerates but based on local autonomous entities, through announcement, 'Measures for boosting social enterprises (June 9, 2011). Moreover the Korean government has a measure that it will strengthen the policy support for social enterprise to induce active involvement of civil society, through which, social enterprises will spread. 
Table 2. Support systems for social enterprise

\begin{tabular}{|c|c|c|c|}
\hline \multirow[b]{2}{*}{ Support system } & \multirow[b]{2}{*}{ Support details } & \multicolumn{2}{|c|}{ Object of support } \\
\hline & & Preliminary & Certified \\
\hline Management support & $\begin{array}{l}\text { Supports management consulting and provides information on } \\
\text { management, tax, labor, and accounting, needed for establishing } \\
\text { social enterprise (certified). } \\
\text { Limit of Support } \\
\text { enterprise:10 20 million won annually, totally } 20 \sim 30 \text { million won for } 3 \text { years } \\
\text { - Preliminary social enterprise: } 3 \text { million won annually, total of } 5 \text { million } \\
\text { won for } 3 \text { years }\end{array}$ & 0 & 0 \\
\hline \multirow[t]{2}{*}{ Tax support } & $\begin{array}{l}50 \% \text { of corporate tax and income tax is exempted for } 4 \text { years in the } \\
\text { case of social enterprise. }\end{array}$ & - & $\circ$ \\
\hline & $\begin{array}{l}\text { The donation shall be included in deductible expenses within } \\
5 \% \text { range of corporate income in the case of connection company } \\
\text { that makes donation to social enterprise. }\end{array}$ & - & o** \\
\hline Supports for social insurance fees & $\begin{array}{l}\text { Partly supports the four social insurance fees that shall be burdened } \\
\text { by a business owner ( } 4 \text { years, } 74,000 \text { won per capita). }\end{array}$ & - & o*** \\
\hline \multicolumn{4}{|l|}{ Financial support } \\
\hline $\begin{array}{l}\text { Support for professional worker } \\
\text { employment }\end{array}$ & $\begin{array}{l}\text { When a social enterprise employs professional workers needed for } \\
\text { business operation such as strategic planning, accounting and } \\
\text { marketing, the labor cost is supported } \\
\text { Limited into } 1.50 \text { million won (for } 3 \text { years, } 3 \text { persons for each } \\
\text { organization, the following self-charges are burdened to a beneficiary } \\
\text { organization). }\end{array}$ & ० & $\circ$ \\
\hline Support for labor cost of social job & $\begin{array}{l}\text { Support of labor cost of participants when a social enterprise is involved } \\
\text { in social job creation business. } \\
\text { Monthly } 932,000 \text { won per capita in } 2010 \text { (including parts of social insurance } \\
\text { fees that should be burdened by a business owner). } \\
\text { * Payment of different support amount for each year } \\
\text { - Preliminary: 1st (100\%), 2nd } 90 \%, 3 \text { rd } 80 \%\end{array}$ & $\circ$ & $\circ$ \\
\hline Support of business development & $\begin{array}{l}\text { Support of business development } \\
\text { followings: } \\
\text { technological development of social enterprise, } R \& D \text {, publicity and } \\
\text { marketing, } \\
\text { * Support limited into } 70 \text { million won for social enterprise and } 30 \text { million } \\
\text { won for preliminary social enterprise, which is burdened by the ratio of }\end{array}$ & $\circ$ & $\circ$ \\
\hline
\end{tabular}

Source: MEL (2011b); *As for the evaluation of public organizations (Ministry of strategy and finance), only social enterprise is an object and as for the evaluation of local autonomous entities (Ministry of public administration and security), preliminary social enterprises are also included; **only non-profit corporate social enterprises are included; *** Only the organizations that are not involved in job creation business

Table 3. Comparison between employment statuses of social enterprises of main countries

\begin{tabular}{llll}
\hline Category & US & Canada & Britain \\
\hline Number of social enterprise & 195,000 & 170,000 & 62,000 \\
Number of employees & $1.4 \mathrm{~m}$ & $3 \mathrm{~m}$ & $2.94 \mathrm{~m}$ \\
Employment ratio (\%) & 9.9 & 17.9 & 12.5 \\
\hline
\end{tabular}

Note: (1) In the case of the US and Canada, the above is the data of 2005, Britain, 2009 and Korea, June 2011. (2) MEL (2011c): Number of employees of social enterprises/Number of employees

Source: Written referring to Lee (2010).

\section{PROBLEMS AND DEVELOPMENT DIRECTION OF SOCIAL ENTREPRISE POLICY}

\subsection{Problem of Policy for Social Enterprise}

Korean social enterprise policy did not start based on the autonomous and creative employment creation that was led by the 3rd sector. However, the enforcement of the said Social Enterprise Promotion Act made 656 social enterprises and more than 1,000 preliminary social enterprises involved in economic activities for implementing the social purpose. During this process, social services or job opportunities are provided to around 30,000 who are from vulnerable social groups, through cooperation between the government, local autonomous 
entities and companies. Moreover for supporting the social enterprise fostering specialized for each business type, the ordinance set-up of local governments of 16 cities and provinces was completed to successfully supplement the system (Ui-seong, 2010).

The Korean social enterprise policy can be evaluated to have achieved remarkable growth in a short term. That is, specialized supporting organizations were established for boosting social enterprises and fostering them through systems and the academy and consignment educational institutes were selected for training social entrepreneurs by each local autonomous entity so that a market condition was formed that can let the spirits of social entrepreneurs inspired

However, there are not a few problems shown in this remarkable growth process. Although an interest in social enterprise is increasing for each region and for each business type, the certifications of social enterprise were shown regionally disproportionate according to deviation for each region, according to the will of a local autonomous entity and the fiscal self-reliance ratio. Furthermore, it is pointed out that it is difficult for creative models of civilians to join social enterprises, since the allowance of certification is too dependent on government policy according to the governmental leading structure. The problems occurring in governmental policy for social enterprise are as following (Eul-sik, 2011).

\subsection{Labor Cost based Support for New Job Creation}

The social enterprise support policy of Korean government is progressed in various fields. However, it is argued that when the characteristic that social enterprise is sought for job creation is reflected, the labor cost supports for new job creation of social enterprise and preliminary social enterprise account for a majority. The labor cost support compared to the overall support was $97 \%$ in 2007 , which fell to $72 \%$ in 2010, but this ratio is still high.

\subsection{Mass-production of Government-dependent Social Enterprise}

Korean social enterprise is managed dependent to the government under the structure the operating loss of social enterprise is supplemented by the funds from the government or local autonomous entities. That is, considering the sales and profit structure of social enterprise, the operating loss of social enterprise was $23.8 \%$ compared to the sales amount on the basis of 2009 and the support amount from the government or local autonomous entities compared to sales amount is $35.7 \%$, which exceeds the operating loss.

\subsection{Certification Program that Bothers Spread of Social Enterprise}

The requirements of social enterprise certification according to the Social Enterprise Promotion Act are very special. That is, the requirements of certification of social enterprise are different according to the types of enterprises, but according to these requirements, in general the employment ratio of vulnerable social group (Type of job creation) and ratio of the social service provision to vulnerable social group (Type of social service provision) should be over $30 \%$. That is to say, only the organization that meets such requirements can be certified as social enterprises.

In fact, the 'Town enterprise' (2010, Ministry of Public Administration and Security, job creation business), farming and fishing rural community enterprise (2011, Ministry for Food, Agriculture, Forestry and Fisheries, community enterprise fostering business), self-support enterprise and cooperative union, whose social type requirements of certification meet the social purpose that are actually managed not by the Ministry of Employment and Labor by other ministries which are excluded from the objects of certification and support of an organization actually performing a role of social enterprise or a social enterprise.

Thus in this case, a social enterprise concept should be widened into not only social enterprise but also non-profit sector and social responsibility enterprise involving profit creation activities and when these organizations meet the criteria, 'the implementation of social purpose', the restriction on the requirements of certification should be eased or these organizations should be defined newly as public corporations so that they can be certified exceptionally through this system supplemental.

In particular, similar policies related to social enterprises are over-issued by egoism and competition of Ministries of Korean government. That is, in that the businesses of other ministries except the Ministry of Employment and Labor have purpose of the boosting of communities and the settlement of local problems they do harm to the self-motivation of communities. In summary, various businesses led by communities are implemented not considering preparation conditions and capacities, so the overlapping of businesses caused by a structure that isolates ministries from each other should be prevented not to wastes resources. 


\subsection{Problems of Fostering the Social Entrepreneurs}

The Korean government decided a short term purpose and progression strategies related to social enterprise policy. First, the short term purpose is: It trains 1,000 social enterprises and creates 50,000 jobs by the end of 2012. As a progression strategy for achieving this aim is that the training system for social enterprise will be improved so that local autonomous entities will take the lead and the central government will assist them actively. That is, the system will be converted from the leading of central government into the market friendly system under which a social enterprise specialized for each region will be found and fostered.

Along with this governmental policy change for social enterprise, social entrepreneurs are fostered through the social entrepreneur academy, youth social entrepreneur academy and social venture business. However the actual fostering of social entrepreneurs is not so efficiently progressed. It is because while the social enterprise policy is progressed by taking the lead by the government, civil involvement such as academy education programs connected with majors of universities is insufficient.

Moreover, the quantitative growth of social enterprise and the training of social entrepreneurs who can run a variety of businesses do not reach an actual desirable level. That is, the causes of complaints of academy education program participants in social entrepreneur training business were shown as lots of overlapping contents $(13.3 \%)$ and insufficient professionalism $(11.2 \%)$. The causes of complaints of professional courses were shown as inappropriate educational period (22.6\%) and overlapping educational contents (12.9\%). Accordingly it is necessary to train social entrepreneurs who have specialized capacities, for a social enterprise to achieve its primary purposes and develop more (Jeonggyu, 2010).

\section{RESULTS AND DISCUSSION}

First, the direction of governmental policy regarding the promotion of social enterprise should be converted into the ecosystem oriented or each business oriented while getting out of the labor cost oriented and should emphasize on the follow up management and evaluation.

Second, the certification program that bothers the expansion of social enterprises should be changed. That is, the government should change a policy into the direction that leaves the activities of social enterprise to the market function while easing the criteria of certification. Only by this, more activities and job creation effects of social enterprise can be expected. Third, the directions of governmental policies related to social entrepreneur fostering should be corrected and complemented. To resolve this problem, so-called, a standard model meaning the policy includes standardized programs and contents for each business, type and local autonomous entity needs to be suggested. The educational programs and contents composed of such a standard model can enhance the professionalism and efficiency in social entrepreneur fostering.

Finally the concept of social economy is needed to spread more widely. That is, as a base of social enterprise activity, systematic and professional educational programs through university or graduate school are required.

The social enterprise history of Korea is very short. However, as for the Korean social enterprise, it is managed by a social enterprise policy uniquely led by the Korean government unlike the models that developed in US and Europe. That is, Korean social enterprise model is a mixed type based on the market leading development model that developed in Britain and US and the 3rd sector typed development model that developed in Italy and the social enterprise policy is led by the Korean government. Such policies that are actively led by the Korean government show the effects that create jobs for the vulnerable social group or provide social services to the vulnerable social group.

As reviewed before, the policy of social enterprise in Korea clearly comes into effect. Such effects have some limitation in a long term since these effects are shown mostly as financial support for social enterprise by the government. Thus the Korean government agrees that the policy should be converted from the support for social enterprise itself to the support for the ecosystem of social enterprise and the policy should put an emphasis on the role of social entrepreneurs who will lead social enterprise.

This study was tried to review the current status and problems of social enterprise in Korea and seek systematical improvement for boosting social enterprise. That is, this study tried to review current status of social enterprise and suggest policy advice on the future development and direction of social enterprise. 


\section{DEVELOPMENT DIRECTION OF TRAINING OF SOCIAL ENTREPRENEUR}

\subsection{Establishment of Specialized Educational Institution of Social Entrepreneurs}

The expansion of social enterprise categories and the active changes of policy of each nation make social entrepreneur actively fostered. The specialized educational programs for training social entrepreneurs are progressed through 33 courses based on the US, Britain and Japan. However, in Korea, such specialized education programs are insufficiently progressed and there is a limit in maintaining and developing social enterprises by current Korean social entrepreneur academy.

Thus, the Korean government should establish and operate specialized educational institutions such as the Ashoka Foundation of the US or School of Social Entrepreneur (SSE) of Britain. These institutions enable social entrepreneurs to strive for the only field of social enterprise and connect the network not only between these social entrepreneurs but also with other worldwide social entrepreneurs. The Ashoka Foundation of the US provides 50,000 dollars for 3 years to social entrepreneurs as active support who have innovative ideas in the US and in the global level and also provides an opportunity of involving the network of around 60 countries to them. Like this, the capacity of social entrepreneurs should be reinforced through exchanges with foreign educational institutes of social entrepreneurs or social entrepreneur research center of university, along with professional training of personnel through establishment of social entrepreneur foundations or non-profit corporations.

\subsection{Program Connected with University Major}

The advanced countries such as the US, Britain and Japan train social entrepreneurs through major course of university or research center. There are 79 courses of University, 23 courses of graduate school and 16 courses of research center over the world. Among them, the US occupies a majority in 16 universities and Europe, 9 universities, Japan 7 universities and Asia, 2 universities: Totally 29 universities over 25 countries operate social entrepreneur courses. It suggests much to Korea that advanced specialized educational institutes are actively involved in a new field called social enterprise by opening social entrepreneur training educational programs in many universities.
In Korea, recently social enterprise related lectures were opened to train social entrepreneurs. Gachon University started to operate the graduate course of social enterprise in the first semester of 2009 and Sungkonghoe University opens 'Self-support and Social Enterprise Major' at the graduate school of Civil Social Welfare, but the social entrepreneur education lectures of Korean Universities still stay at the level of providing and reviewing just basic information on social enterprise and social entrepreneurs and rarely operate the courses that handle creativity and ethical disposition.

Furthermore, the problem can be pointed out that courses are composed of subjects based on theoretical lectures rather than providing a chance to experience social enterprise directly.

\section{CONCLUSION}

The social enterprise history of Korea is very short. However, as for the Korean social enterprise, it is managed by a social enterprise policy uniquely led by the Korean government unlike the models that developed in US and Europe. That is, Korean social enterprise model is a mixed type based on the market leading development model that developed in Britain and US and the 3rd sector typed development model that developed in Italy and the social enterprise policy is led by the Korean government. Such policies that are actively led by the Korean government show the effects that create jobs for the vulnerable social group or provide social services to the vulnerable social group.

As reviewed before, the policy of social enterprise in Korea clearly comes into effect. Such effects have some limitation in a long term since these effects are shown mostly as financial support for social enterprise by the government. Thus the Korean government agrees that the policy should be converted from the support for social enterprise itself to the support for the ecosystem of social enterprise and the policy should put an emphasis on the role of social entrepreneurs who will lead social enterprise.

This study was tried to review the current status and problems of social enterprise in Korea and seek systematical improvement for boosting social enterprise. That is, this study tried to review current status of social enterprise and suggest policy advice on the future development and direction of social enterprise. The policy improvements for social enterprise pointed out by this study are as follows.

First, the social enterprise support policy by the Korean government is sought in various fields, but the support for labor cost for new job creation occupies the 
most proportion. Thus, to improve this problem, the support should be implemented for each business, for each region and for each program rather than the direct support for labor costs of the relevant enterprise and should be changed from direct support to indirect support that supports the ecosystem of social enterprise.

Second, the certification program that bothers the expansion of social enterprise is also a problem. That is, the government dependent social enterprise is produced under an idea that the requirements of certificate of the government are particular but if a social enterprise succeeds in being certified, everything will be OK. In summary, for improving this problem, the criteria of governmental certification should be eased while policy should be changed into a direction that the activity of social enterprise is left at the disposal of market function. This is necessary for social enterprises to improve profit ratios in the current operating loss structure in terms of operating activity. When this improvement is achieved, as a whole, more social enterprise activities and job creation effects can be expected and the government also can complement the policies more, decreasing the government dependent social enterprises that are burdensome.

Third, it is needed to correct and supplement the governmental policy on the training of social entrepreneurs. To resolve this problem, it is required to suggest a standard model of social entrepreneur train business. Here, the standard model means that the social entrepreneur train business includes educational programs and contents standardized for each business, type and local autonomous entity. These kinds of educational programs and contents will enhance the professionalism and efficiency in training social entrepreneurs.

Finally the recognition on social economy is needed to spread under the connection with the social entrepreneur train business. The social economy is a base where social enterprises can deploy activities. Since the training of social entrepreneurs without spread in the level of social economy is just the training of functionalists and technicians, the social awareness needs to change. In summary, it can be said that professional educational programs that systematically educate social entrepreneurs through education in university and graduate school is required.

\section{ACKNOWLEDGEMENT}

This study was supported by Konkuk University.

\section{REFERENCES}

Eul-sik, K., 2011. Roles of social enterprise and government. Issue Diagnosis, Gyeonggi Development Institute.

Jeong-gyu, Y., 2010. Survey on the actual condition of strategies for fostering social enterprise; region sector. Local Foundation, Service report of Ministry of Employment and Labor

KED, 2011. A new experiment, Social Enterprise the fourth year. Korea Social Enterprise Promotion Agency.

Lee, C.S., 2010. Measure for enterprise involvement for boosting social enterprise. national assembly data of policy discussion for boosting social enterprise.

MEL, 2011a. Measures for boosting social enterprise. Press Release.

MEL, 2011b. Measure for boosting financial raising of social enterprise through capital market. KDI FOCUS, Korea Development Institute.

MEL, 2011c. Social enterprise, now its competitiveness is important. Press Release.

MEL, 2012. Current status of social enterprise and policy implications. Ministry of Employment and Labor.

$\mathrm{SN}$, 2011. Easy credit discussion involving social enterprises.

Ui-seong, J., 2010. Policy for sustainable fostering of social enterprise, national assembly data of policy discussion for boosting social enterprise. 